\title{
Metabolic engineering of the Lactococcus lactis diacetyl pathway
}

\author{
MJ Gasson, K Benson, S Swindell, H Griffin
}

Institute of Food Research, Norwich Research Park, Colney Lane, Norwich NR4 7UA, UK

\begin{abstract}
Summary - Inactivation of the gene for lactate dehydrogenase caused a significant change to metabolic flux with the elimination of lactic acid as a metabolic end product and production of ethanol, formate and acetoin. Acetoin production by $I d h$ defective $L$ lactis growing on sugar was comparable with that by a diacetylactis biovar growing on both sugar and citrate. The overexpression of biosynthetic $\alpha$ acetolactate synthetase encoded by ilvBN genes also led to increased acetoin production in $L$ lactis. The inactivation of the ald $B$ gene encoding $\alpha$-acetolactate decarboxylase increased the production of $\alpha$-acetolactate and diacetyl at the expense of acetoin.
\end{abstract}

Lactococcus lactis / genetic engineering / diacetyl / lactate dehydrogenase / $\alpha$-acetolactate

Résumé - Ingénierie génétique de la voie du diacétyle chez Lactococcus lactis. Cet article rapporte les effets des modifications génétiques sur la voie du diacétyle. L'inactivation du gène de la lactate deshydrogénase provoque un changement significatif du flux métabolique avec l'élimination d'acide lactique comme produit final ainsi que la production d'éthanol, d'acide formique et d'acétoine. La production d'acétoïne par des souches de L lactis mutées pour le gène Idh est comparable à celle du biovar diacetylactis en milieu contenant du glucose et du citrate. La surproduction de la synthétase d' $\alpha$-acétolactate codée par les gènes ilvBN chez L lactis conduit également à une production accrue d'acétoïne. L'inactivation du gène aldB codant la décarboxylase d' $\alpha$-acétolactate augmente la production d' $\alpha$-acétolactate et de diacétyle au détriment d'acétoïne.

Lactococcus lactis / ingénierie génétique / diacétyle / lactate deshydrogénase / $\alpha$-acétolactate

\section{INTRODUCTION}

Lactic acid bacteria convert sugars to lactic acid via the intermediate pyruvate and certain strains, including diacetylactis biovars of Lactococcus lactis subsp lactis, ferment citrate that is converted to pyruvate. These latter strains metabolize the excess pyru- vate by additional pathways and this can lead to formation of the flavour compound diacetyl (fig 1). The enzyme $\alpha$-acetolactate synthase (ALS; EC 4.1.3.18) converts pyruvate to $\alpha$-acetolactate and this unstable intermediate is converted to acetoin by $\alpha$ acetolactate decarboxylase (ALD; EC 4.1.1.5; Hugenholtz, 1993) or by chemical decarboxylation (Hugenholtz, 1993). In addi- 
tion, the $\alpha$-acetolactate can undergo oxidative decarboxylation to form diacetyl. Increased levels of acetoin and diacetyl are found under aerated conditions (Bassit et al, 1993) and this may be due in part to the increased activities of $\alpha$-acetolactate synthase and NADH oxidase (Bassit et al, 1993) or to decreased pyruvate-formate lyase activity (Starrenburg and Hugenholtz, 1991). The enzyme diacetyl-acetoin reductase catalyses the reduction of vicinal diketones and the subsequent reversible reduction of the monohydroxy carbonyl products. This enzyme converts diacetyl to acetoin and acetoin to 2,3-butanediol.

Diacetyl is a desirable flavour component in dairy products and there is interest in the construction of $L$ lactis strains which generate increased yields of diacetyl. This might be achieved by a metabolic engineering approach and in general this lactococcal pathway provides a good model system with which to analyse metabolic flux and the consequences of changed levels of enzyme activity. We, in collaboration with others (W DeVos,NIZO and P Renault, Inra) have initiated genetic manipulation of the biochemical pathway involved in diacetyl production focussing on enzymes that might be expected to influence the yield of diacetyl. Here we summarize the work conducted in our laboratory. A number of genes encoding key enzymes were targeted for cloning, sequencing and manipulation. These included the Idh gene, encoding lactate dehydrogenase; the ilvBN genes encoding an $\alpha$-acetolactate synthase; the ald $B$ gene encoding acetolactate decarboxylase; the dar gene encoding diacetyl-acetoin reductase; the oad gene encoding oxaloacetate decarboxylase; and the pfl gene encoding pyruvate formate lyase. The genes $I d h$, ald $B$ and $i l v B N$ have been used in metabolic engineering experiments.

\section{RESULTS AND DISCUSSION}

\section{The Idh gene encoding lactate dehydrogenase}

In L lactis pyruvate is converted to lactate by the enzyme lactate dehydrogenase. It was anticipated that eliminating or decreasing the activity of this enzyme would elevate the amount of pyruvate present in the cell, mimicing the situation in citrate fermenting strains such as $L$ lactis subsp lactis biovar diacetylactis. The increased pyruvate pool

\section{LACTOSE $\stackrel{\substack{\text { lactose } \\ \text { PTS }}}{\rightarrow}$ LACTOSE 6-PHOSPHATE}

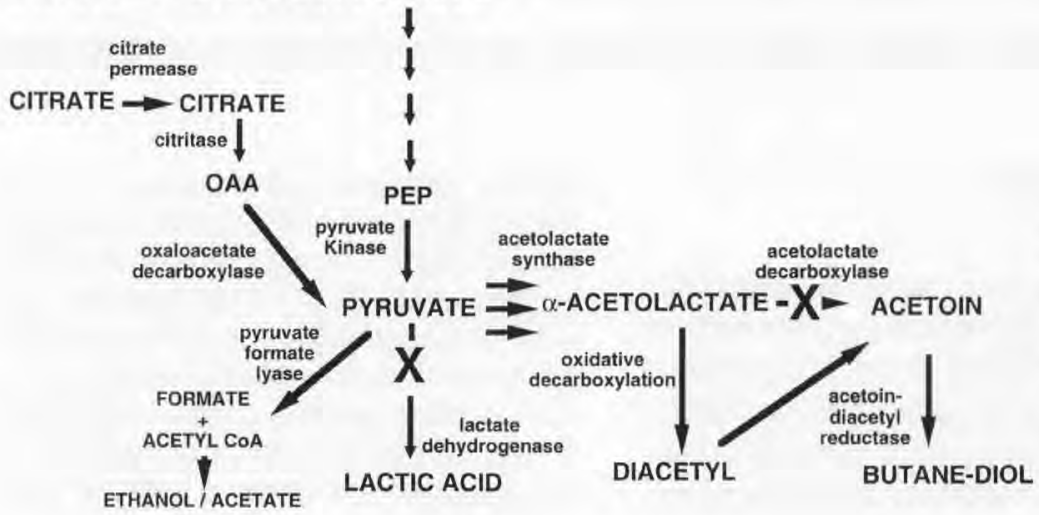

Fig 1. The pathway for diacetyl metabolism in L lactis. Voie métabolique $d u$ diacétyle chez L lactis. 
would then be available for metabolism by additional pathways resulting in acetoin and diacetyl production.

The $\mathrm{N}$-terminal amino acid sequence and the sequence of a tryptic peptide from the $L$ lactis subsp cremoris lactate dehydrogenase enzyme were used to design oligo primers. These primers were used to PCR amplify an 800-bp fragment from total genomic DNA of $L$ lactis subsp cremoris MG1363. This fragment showed DNA sequence homology with the Idh genes of other organisms and was subsequently cloned into the Smal site of pUC13 to yield plasmid pFI514.

The 800-bp fragment was used to probe a lambda library of $L$ lactis and DNA from several plaques which gave positive signals was isolated. The DNA from one PCR positive clone was digested with a range of restriction enzymes and electrophoresed on an agarose gel. A Southern hybridization experiment showed that the $800-b p$ probe hybridized to a single $1.3 \mathrm{kbp}$ Hind III band and a single $6.0 \mathrm{kbp}$ EcoRV band. These fragments were subcloned into the Hindll site of pUC18 (to yield plasmid $\mathrm{pFI515}$ ) and the Smal site of pUC13 (to yield $\mathrm{pFI516)}$ respectively. The plasmids were used to determine the DNA sequence of a $1.2 \mathrm{kbp}$ region containing the entire $L$ lactis Idh gene (Swindell et al, 1994).

In order to inactivate the gene for lactate dehydrogenase a truncated / $d$ h gene (missing both the 5' and the 3' regions) was integrated into the chromosome of MG1363
(Gasson, 1983) by a single cross-over event. This was achieved by transformation of $L$ lactis subsp cremoris MG1363 with plasmid pFI658, a construct which has an $E$ coli replicon precluding replication in $\mathrm{L}$ lactis, an erythromycin resistance gene that is selectable in L lactis and an internal fragment of the ldh gene that provides homology for chromosomal integration. The derived strain, Fl7851, possesses two dysfunctional copies of the $/ d h$ gene. This $/ d h$ mutant strain lacked lactate dehydrogenase activity and during growth on glucose produced very low levels of lactate but increased levels of acetoin (table I). This strain generated a similar amount of acetoin during sugar fermentation to that produced by $L$ lactis subsp lactis biovar diacetylactis strains growing on both sugar and citrate.

\section{The aldB gene encoding $\alpha$-acetolactate decarboxylase}

Inactivation of the gene encoding $\alpha$-acetolactate decarboxylase should prevent the enzymatic conversion of $\alpha$-acetolactate to acetoin, thereby increasing the opportunity for its oxidative decarboxylation to form diacetyl. Oligonucleotide primers for use in PCR amplification were designed from the sequence of the ald $B$ gene of $L$ lactis IL1403 (JJ Godon, SD Ehrlich, personal communication). These primers were subsequently used to identify individual clones containing the aldB gene from a lambda library of $L$

Table I. The effect of $/ d h$ gene inactivation on L lactis fermentation. Effet de l'inactivation du gène ldh sur la fermentation de $L$ lactis.

\begin{tabular}{lcccr} 
Strain & Idh & $\begin{array}{c}\text { LDH activity } \\
\left(U \mu g^{-1}\right)\end{array}$ & $\begin{array}{c}\text { Lactate } \\
(\mathrm{mmol} / \mathrm{l})\end{array}$ & $\begin{array}{r}\text { Acetoin } \\
(\mathrm{mmol} / \mathrm{l})\end{array}$ \\
\hline MG 1363 & + & $1.157 \times 10^{-1}$ & 53 & 4.0 \\
FI17851 & - & $7.8 \times 10^{-3}$ & 2.2 & 17.0
\end{tabular}


lactis subsp cremoris MG1363 using the direct PCR screening method (Griffin et al, 1993; Griffin, 1994). Positive clones were identified in this way and an insert fragment was excised and maintained as plasmid pFI937. The DNA sequence of the aldB gene of MG1363 was determined and has been submitted to the DNA databank (accession number $\mathrm{X82620)}$ ). The aldB DNA sequence from $L$ lactis subsp cremoris MG1363 shows $89 \%$ identity with the equivalent sequence from IL1403. The aldB gene of $L$ lactis subsp cremoris MG1363 encodes a predicted protein sequence of 236 amino acids with a molecular mass of $26 \mathrm{kDa}$. The predicted amino acid sequence shows $97.5 \%$ identity with the equivalent sequence from IL $1403 ; 36 \%$ identity $(63 \%$ similarity) with the Bacillus brevis sequence (Diderichsen et al, 1990); $34 \%$ identity (60\% similarity) with the $B$ subtilis sequence (Renna et al, 1993); $36 \%$ identity (58\% similarity) with the Enterobacter aerogenes sequence (Sone et al, 1988); $34 \%$ identity ( $58 \%$ similarity) with the Klebsiella terrigena sequence (Blomqvist et al, 1993); and 29\% identity ( $56 \%$ similarity) with the Coxiella burnetii sequence (unpublished, GenBank accession number U14393). A multiple alignment of all seven sequences shows two highly conserved regions (amino acids 34-49 and 171-188 on the MG1363 sequence) that probably represent the active site, and substrate or co-factor binding site.

PCR primers were designed to amplify a $1.4 \mathrm{kbp}$ DNA fragment from the region of pFI937 immediately upstream of the start site of $a / d B$. The amplified fragment was cloned into the cloning vector pCRIl to generate plasmid $\mathrm{pF}$ 1777. A combined $2.8 \mathrm{kbp}$ insert was subcloned into the BamHI site of pG+host 6 to form pFI805. The insert of plasmid pFI805 is, in effect, a region of lactococcal chromosomal DNA lacking the entire $a l d B$ gene and it was used to delete the chromosomal ald $B$ gene of $L$ lactis by a double cross-over recombination event using the temperature sensitive replicon of pG+host6. L lactis subsp cremoris MG1363 was transformed with plasmid $\mathrm{pFI} 805$ at the permissive temperature $\left(28^{\circ} \mathrm{C}\right)$ with selection for erythromycin. The temperature was then shifted to the restrictive temperature $\left(37^{\circ} \mathrm{C}\right)$ at which plasmid replication was disabled. Subsequent growth on erythromycin enabled the selection of cells in which the plasmid had integrated into the chromosome (single cross-over integration). Further growth of these strains at $28^{\circ} \mathrm{C}$ enabled the detection of erythromycin-sensitive cells in which the second cross-over (excision) event had occurred. PCR analysis was employed to identify double cross-over recombinants containing an ald $B$ deletion and to confirm the chromosomal structure. One of the recombinants, strain Fl8076, was chosen for further study.

MG1363 was found to express a similar level of $\alpha$-acetolactate decarboxylase activity to the levels expressed by other $L$ lactis strains (Monnet et al, 1994; Phalip et al, 1994). $\alpha$-Acetolactate decarboxylase activity was stimulated ten-fold by the addition of leucine, as observed previously (Monnet et al, 1994; Phalip et al, 1994). No $\alpha$-acetolactate decarboxylase activity was detected, in the absence or presence of leucine, in Fl8076 cultures. Deletion of the $a / d B$ gene had a significant effect on the pattern of fermentation end-products. In contrast to MG1363, the aldB deletion strain Fl8076 produced increased quantities of $\alpha$ acetolactate and diacetyl at the expense of acetoin (table II).

\section{The ilvBN genes encoding $\alpha$-acetolactate synthase}

The $\alpha$-acetolactate synthase normally active in the diacetyl production pathway has a low affinity for pyruvate (Snoep et al, 1992; Monnet et al, 1994) and pyruvate is not 
diverted into this pathway unless it is present in excess as for example during citrate fermentation by $L$ lactis subsp lactis biovar diacetylactis (Hugenholtz, 1993). The als gene encoding this enzyme has been characterized by Marugg et al (1994). Recently the genes ilvBN encoding another lactococcal acetohydroxy acid synthase IlvBN have been described (Godon et al, 1992). Enzymes homologous to llvBN convert pyruvate to $\alpha$-acetolactate during branched-chain amino acid biosynthesis (Umbarger, 1987) and transcript analysis has shown that the ilv $B N$ operon is not transcribed when branched-chain amino acids are supplied in the medium for example during growth in milk (Godon et al, 1993). IlvBN consists of two subunits and has a higher affinity for pyruvate (Godon et al, 1992; K Benson, H Griffin, M Gasson, unpublished). In order to increase flux of pyruvate into the diacetyl production pathway the ilvBN genes were expressed from the heterologous lactococcal promoter P32 (Van der Guchte, 1991; Van der Guchte et al, 1992; Van der Vossen et al, 1987). Such constitutive I/vBN expression allowed $\alpha$-acetolactate synthase activity in the presence of branched-chain amino acids and increased the generation of diacetyl and acetoin in several $L$ lactis strains.

A DNA fragment encoding the ilvBN genes was constructed using a combination of gene cloning and PCR amplification. The 5 ' region was redesigned for expression under the control of a heterologous promoter and the fragment was inserted between the Sstl and Sal sites of the vector pMG36e, downstream of promoter P32 to yield plasmid $p F I 749$. Plasmid $p F I 749$ was used to express the ilvBN genes in L lactis strains MG1363, IL1403, FI8076 and JIM4882. The latter two strains lack $\alpha$-acetolactate decarboxylase activity. $L$ lactis FI8076 is described above and L lactis JIM4882 is a derivative of IL1403 from which the chromosomal ilv and the flanking leu and ald operons have been deleted (JJ Godon, P Renault, unpublished results). Strains harboring plasmid $\mathrm{pFI} 749$ showed increased production of $\alpha$-acetolactate, acetoin and diacetyl (table II).

\section{Other genes}

The multiple alignment of amino acid sequences from databases together with

Table II. The effect of $i l V B N$ overexpression and aldB gene inactivation on $L$ lactis fermentation. Effet de la surexpression du gène ilvBN et de l'inactivation du gène aldB sur la fermentation de L lactis.

\begin{tabular}{|c|c|c|c|c|c|c|}
\hline \multirow[t]{2}{*}{ Strain } & \multirow[t]{2}{*}{ Subspecies } & \multicolumn{2}{|c|}{ Genotype } & \multirow{2}{*}{$\begin{array}{c}\alpha \text {-acetolactate } \\
(\text { mmol/l) }\end{array}$} & \multirow{2}{*}{$\begin{array}{l}\text { Acetoin } \\
(\text { mmol/I) }\end{array}$} & \multirow{2}{*}{$\begin{array}{l}\text { Diacety } \\
(\mathrm{mmol} / \mathrm{l})\end{array}$} \\
\hline & & $\begin{array}{c}\text { chromosomal } \\
\text { aldB }\end{array}$ & $\begin{array}{l}\text { plasmid } \\
\text { ilvBN }\end{array}$ & & & \\
\hline MG1363 & cremoris & + & - & 0 & 0.85 & 0 \\
\hline $\mathrm{Fl} 8001$ & cremoris & + & + & 0 & 3.08 & 0.02 \\
\hline FI8076 & cremoris & - & + & 0.52 & 0.30 & 0.32 \\
\hline Fl8191 & cremoris & + & + & 1.48 & 0.73 & 0.53 \\
\hline IL1403 & lactis & + & - & 0 & 1.28 & 0.05 \\
\hline FI8046 & lactis & + & + & 0 & 3.25 & 0.08 \\
\hline JIM4882 & lactis & - & - & 0 & 0 & 0 \\
\hline F17979 & lactis & - & + & 0.41 & 0.21 & 0.10 \\
\hline
\end{tabular}


redundant primer design and PCR amplification have been used to identify further genes that are relevant to diacetyl production. The oxaloacetate decarboxylase gene involved in the conversion of citrate to pyruvate and the diacetyl-acetoin reductase gene involved in the interconversion of diacetyl, acetoin, and 2,4-butanediol have been isolated. Work is currently under way to analyse these genes and exploit them in additional metabolic engineering strategies. The gene coding for pyruvate formate lyase has also been targeted for cloning and manipulation as inactivation of this gene could lead to increased availability of pyruvate for conversion to $\alpha$-acetolactate.

An important aspect of diacetyl production is the use of aeration to inhibit pyruvate formate lyase and increase the pyruvate pool that is available for conversion to $\alpha$-acetolactate. There is thus interest in the influence of oxygen on gene expression in $L$ lactis. In Gram-negative bacteria FNRtype regulators function as redox responsive control proteins in a range of different systems. These proteins are related to the cyclic AMP receptor protein (CRP or CAP) which activates catabolite-sensitive genes in response to intracellular CAMP and the CRP-FNR family contains at least 17 structurally-related transcriptional regulators. They are site-specific DNA-binding proteins possessing C-terminal helix-turn-helix motifs in their DNA-binding domains and $B$-roll structures in their nucleotide-binding or sensory domains and they activate or repress the transcription of target genes in response to metabolic or environmental stimuli. A multiple alignment was produced of the amino acid sequences of CRP-FNR type proteins from various bacteria and PCR primers were designed from areas of conservation based on the lactococcal codon usage table. These degenerate primers were used in a PCR reaction to amplify DNA fragments from the chromosome of MG1363 and subsequently clones con- - taining genes for FNR-like proteins were isolated. DNA sequence analysis of two such genes has been performed. The predicted amino acid sequences of the two flp genes show approximately $60 \%$ homology (D Gostick, H Griffin, M Gasson, unpublished data).

\section{DISCUSSION}

Diacetyl is an important flavour compound in the dairy industry, providing the characteristic 'buttery' flavour of many fermented milk products. It is normally produced by a limited number of strains of lactic acid bacteria, such as $L$ lactis subsp lactis biovar diacetylactis and its generation depends on citrate utilization (Hugenholtz, 1993). Here we describe a metabolic engineering approach to alter the activities of some key enzymes involved in the generation of diacetyl and demonstrate that changes in metabolic flux leading to altered patterns of fermentation end-products can be achieved.

As already described diacetyl production depends on citrate utilization leading to an increased pyruvate pool and its dissipation via several metabolic routes including conversion to the diacetyl precursor $\alpha$ acetolactate. Deletion of the Idh gene encoding lactate dehydrogenase facilitated conversion of pyruvate to $\alpha$-acetolactate when $L$ lactis is grown on sugar in the absence of citrate. The yields of $\alpha$-acetolactate derivatives were equivalent to those obtained for $L$ lactis subsp lactis biovar diacetylactis strains utilizing citrate as well as sugar. The fact that higher levels were not found when the pyruvate pool was significantly increased in the ldh mutants suggests that the low affinity of $\alpha$-acetolactate synthase for pyruvate is a rate limiting step. This has been addressed by the constitutive expression of an anabolic $\alpha$-acetolactate synthase IIvBN that is normally 
involved in amino acid biosynthesis and subject to transcriptional regulation. Expression of the ilvBN genes under the control of a constitutive promoter in L lactis led to increased conversion of pyruvate to $\alpha$-acetolactate and this led to changed fermentation end products. This effect is probably due to the higher affinity of the IIvBN $\alpha$-acetolactate synthase for pyruvate and in the longer term it is conceivable that a protein engineering approach might be used to improve the affinity of $\alpha$-acetolactate synthases for pyruvate and this might further increase the entry of pyruvate into the diacetyl generation pathway. In industry the production of diacetyl depends on a natural mutant of $L$ lactis subsp lactis biovar diacetylactis that lacks $\alpha$-acetolactate decarboxylase activity. The block in the enzymatic conversion of $\alpha$-acetolactate into acetoin facilitates its chemical conversion into diacetyl by oxidative decarboxylation. This effect was reproduced by the use of a genetic engineering strategy in which the ald $B$ gene was deleted from the chromosome of $L$ lactis.

The experiments described here clearly illustrate the potential of a metabolic engineering approach to influence the yield of a desirable metabolite. There remains considerable potential to further develop this approach. It would be interesting to stack the genetic changes that have been described individually and experiments are in progress to construct a $/ d h^{-}$ald $B^{-}$double mutant and to overexpress ilvBN in a $/ \mathrm{dh}^{-}$ mutant. Genes for additional enzymes might also be exploited and to this end the gene for diacetyl reductase has already been cloned and that for pyruvate formate lyase is being sought. Attention might also be given to cofactor regeneration and the control of gene expression in response to oxygen. With respect to this last point it is of interest that lactococcal genes homologous to FNRlike regulators have recently been characterized.

\section{REFERENCES}

Bassit N, Boquien CY, Picque D, Corrieu G (1993) Effect of initial oxygen concentration on diacetyl and acetoin production by Lactococcus lactis subsp lactis biovar diacetylactis. Appl Environ Microbiol 59 , 1893-1897

Blomqvist K, Nikkola M, Lehtovaara P, Suihko ML, Airaksinen U, Stráby KB, Knowles J KC, Penttila ME (1993) Characterization of the genes of the 2,3butanediol operons from Klebsiella terrigena and Enterobacter aerogenes. J Bacteriol 175, 1392-1404

Diderichsen B, Wedsted U, Hedegaard L, Jensen BR, Sjøholm C (1990) Cloning of aldB, which encodes $\alpha$ acetolactate decarboxylase, an exoenzyme from Bacillus brevis. J Bacteriol 172, 4315-4321

Gasson MJ (1983) Plasmid complements of Streptococcus lactis NCD0712 and other lactic streptococci after protoplast induced curing. J Bacteriol 154, 1-9

Godon JJ, Chopin MC, Ehrlich SD (1992) Branchedchain amino acid biosynthesis genes in Lactococcus lactis subsp lactis. J Bacteriol 174, 6580-6589

Godon JJ, Delorme C, Bardowski J, Chopin MC, Ehrlich $S D$, Renault $P(1993)$ Gene inactivation in Lactococcus lactis: branched-chain amino acid biosynthesis. J Bacteriol 175, 4383-4390

Griffin HG (1994) Direct PCR screening of lambda and cosmid libraries. In: PCR Protocols: Current Innovations (HG Griffin, AM Griffin, eds) CRC Press, Boca Raton, Florida, 53-57

Griffin HG, l'Anson KJ, Gasson MJ (1993) Rapid isolation of genes from bacterial lambda libraries by direct PCR screening. FEMS Microbiol Lett 112, 4954

Hugenholtz J (1993) Citrate metabolism in lactic acid bacteria. FEMS Microbiol Rev 12, 165-178

Marugg JD, Goelling D, Stahl U, Ledeboer AM, Toonen MY, Verhue WM, Verrips CT (1994) Identification and characterization of the $\alpha$-acetolactate synthase gene from Lactococcus lactis subsp lactis biovar diacetylactis. Appl Environ Microbiol 60, 1390-1394

Monnet C, Phalip V. Schmitt P, Diviès C (1994) Comparison of $\alpha$-acetolactate synthase and $\alpha$-acetolactate decarboxylase in Lactococcus spp and Leuconostoc spp. Biotechnol Lett 16, 257-262

Phalip V, Monnet C, Schmitt P, Renault P, Godon JJ, Diviès C (1994) Purification and properties of the $\alpha$-acetolactate decarboxylase from Lactococcus lactis subsp lactis NCDO 2118. FEBS Lett 351 , 95-99

Renna MC, Najimudin N, Winik LR, Zahler SA (1993) Regulation of the Bacillus subtilis alsS, alsD, and als $R$ genes involved in post-exponential-phase production of acetoin. J Bacteriol 175, 3863-3875

Snoep JL, Teixeira de Mattos MJ, Starrenburg MJC, Hugenholtz $\mathrm{J}(1992)$ Isolation, characterization, and 
physiological role of the pyruvate dehydrogenase complex and $\alpha$-acetolactate synthase of Lactococcus lactis subsp lactis bv diacetylactis. J Bacteriol 174, 4838-4841

Sone H, Fujii T, Kondo K, Shimizu F, Tanaka JI, Inoue T (1988) Nucleotide sequence and expression of the Enterobacter aerogenes $\alpha$-acetolactate decarboxylase gene in brewer's yeast. Appl Environ Microbiol $54,38-42$

Starrenburg MJC, Hugenholtz J (1991) Citrate fermentation by Lactococcus and Leuconostoc spp. Appl Environ Microbiol 57, 3535-3540

Swindell SR, Griffin HG, Gasson MJ (1994) Cloning, sequencing and comparison of three lactococcal Llactate dehydrogenase genes. Microbiology 140, 1301-1305
Umbarger HE (1987) Biosynthesis of branched-chain amino acids. In: Escherichia coli and Salmonella typhimurium: cellular and molecular biology (FC Neidhardt, JL Ingraham, KL Low, B Magasanik, M Schaechter, HE Umbarger, eds) American Society for Microbiology, Washington, DC, 352-367

van de Guchte M (1991) Expression hétérologue chez $L$ lactis. PhD thesis, University of Groningen, the Netherlands

van de Guchte M, Kok J, Venema G (1992) Gene expression in Lactococcus lactis. FEMS Microbiol Rev 88, 73-92

van der Vossen JMBM, van der Lelie D, Venema G (1987) Isolation and characterization of Streptococcus cremoris Wg2-specific promoters. Appl Environ Microbiol 53, 2452-2457 